\title{
Re-examining the Role of Teacher Trade Unions' in Promoting Welfare and Sustained Livelihood for their Members: A Case of Teacher Trade Unions in Lusaka, Zambia
}

\author{
Kakunta M Kabika, Simuyaba Eunifridah, Haambokoma Nicholas and Mwewa Godfrey \\ Department of educational Administration and Policy Studies, The University of Zambia
}

\begin{abstract}
We investigated the role of teacher trade unions in promoting teacher welfare and sustained livelihood for their members in Lusaka District of Zambia. The objectives of the study were to; explore how the teacher unions have helped in promoting teacher welfare and sustained livelihood; and determine measures that teacher unions can take to support the teacher welfare and sustained livelihood. A descriptive study design was employed on a target population that comprised four (4) national teacher union officials targeting one (1) official from each of the four national teacher trade union secretariats, 16 teachers, and 16 union leaders at school level of selected schools. Purposive sampling method was used to sample national teacher trade union officials and four school level union leaders from selected primary and secondary schools in Lusaka District. Data was collected through interviews; focus group discussion; and documentary review were thematically analyzed and interpreted, respectively. The study revealed that teacher trade unions were instrumental in providing legal representation of members and in collective bargaining, but their role did not effectively result in motivational conditions of service for promoting enhanced teacher welfare and sustained livelihood. The study recommended that provision of non-traditional incentives such as; education assistance; facilitation of land acquisition; funeral support; financial benefits; health scheme; mortgage; decentralization of functions would have positive impact on teacher welfare and sustained livelihood. The study also recommended that teacher trade unions needed to reposition themselves by re-organizing themselves through employing more innovation as opposed to following traditional approaches to improving member benefits. Teacher trade unions further needed to focus on knowledge empowerment for lower level union leadership structures at school level in order to improve representation of teachers, enhance workers' education and to diversify into sustainable business ventures that would enhance the union funds, and develop pool fund to be used to empower members.
\end{abstract}

Keyword: Teacher Unions, Role, Teacher welfare, Sustained Livelihood.

\section{INTRODUCTION}

$\mathrm{T}$ rade unions world over are workers' organizations formed with a key objective of ensuring that the welfare and living standard of workers are improved to meet their economic wellbeing. At global level, the International Labour
Organization Convention number 89 has been one of the key reference documents on the rights of workers at the workplace focusing on the right to organize. World over, workers organize themselves through workers' trade unions with a view to ensuring that their interests and rights at the workplace are protected. This further establishes a platform where their conditions of service could be improved and protected (Harris, 2010).

In Zambia, the Industrial and Labour Relations Act CAP 269 Part II of the Laws of Zambia provides for the establishment of workers' organizations (trade unions) whose role is to ensuring that the welfare of workers are protected in both public and private sectors of the Zambian workforce. There are three mother body trade unions namely Zambia Congress of Trade Union (ZCTU) with forty-six trade unions affiliated to it; the Federation of Free Trade Union in Zambia (FFTUZ) which has twelve (12) affiliates, and the most recent federation with only three members the Confederation of Trade Union in Zambia (COTUZ) (MLSS, 2016). The total number of trade unions according to the Ministry of Labour and Social Security (2016) are sixty-one (61) trade unions in Zambia.

In the Zambian education sector, there are currently five teacher unions with the oldest being the Zambia National Union of Teachers (ZNUT) with its recognition agreement dating back to 1964 when it was signed between ZNUT and the Ministry of Education (ZNUT, 2006). The other more recent teacher unions include; Basic Education Teachers Union of Zambia (BETUZ); Secondary School Teachers Union of Zambia (SESTUZ), Professional Teachers Union of Zambia (PROTUZ), and the most recently formed, which is the National Union of Public and Private Educators of Zambia (NUPPEZ), (MLSS, 2018).

The advocacy point and claim by all the five teacher trade unions revolve around effective member representation and a pledge for better teacher welfare through the protection of their rights and effective collective bargaining for improved teacher welfare and sustained livelihood would meet the global minimum standards. 
Despite the many historical gains that the teacher trade unions have scored over time, there still remains a growing concern among their members that they have been able to achieve their objective of improving their welfare and sustained livelihood for them. Some studies (Ratteree, 2004; Patillo, 2012) have shown that some splinter unions were formed due to member dissatisfaction with the operations of the old teacher unions. Teacher trade unions on the other hand have continued to claim that a lot is being done for their members with a clear focus on making sure that their lives are improved. Among the key achievements by the trade union include conducting workers' education, increasing co-operation and well-being among workers, securing facilities and benefits for workers, establishing dialogue platforms between the workers and the employers, advocating for career progression for employees, safeguarding the interests of the workers, and provision of labour welfare. (Mwilima, 2008).

Studies in education (Hugget (1996) have also demonstrated that teacher welfare and sustained livelihood are a key element that contribute to improved teacher performance which is very critical for the management and provision of quality education world over. This is achievable through effective collective bargaining by the unions which is a process of negotiation between employers and the workers (through the union) on terms and conditions of employment visa vis salaries, working conditions, benefits, and other aspects of workers' compensation and rights (Herman (1998). It is however, the opinion of the teacher members in Zambia their unions are not doing enough despite receiving 'a lot' of money in form of membership subscription (ILO, 2004). It is against this background that this study was undertaken with a view to explore the role of teacher unions in promoting welfare and sustained livelihood of members.

\section{Statement of the Problem}

Teacher unions in Zambia have a mandate of promoting improved teacher welfare and sustained livelihood. This is done through a number of programs as provided for in the Industrial and Labour Relations Act CAP 269 of the Laws of Zambia. Studies conducted elsewhere in Africa revealed that teacher trade unions have been taking a number of initiatives in improving teacher welfare thereby promoting sustained livelihood for their teacher members through the introduction of incentives which impact their wellbeing positively (Mwilima, (2008). Despite this a study by Maravi (2002) highlighted the challenges teacher trade unions face in providing sustainable social welfare and incentives to their members, and that it's due to limited funds. Hugget (1996) however, observed that teachers in Zambia have been calling on teacher trade unions to account for the utilisation of their subscription as the unions do not seem use the same for the intended programs and instead selfishly improve their own livelihood. It is against this background that this study was conducted in order to investigate the role of teacher unions in promoting improved welfare and sustained livelihood of members in Lusaka district.

\section{RESEARCH OBJECTIVES}

The study explored how the teacher trade unions' role has helped in promoting teacher welfare and sustained livelihood in Lusaka District. The study also sought to determine the effectiveness of the measures and strategies that teacher trade unions may take to support the teacher welfare and sustained livelihood in Lusaka District.

\section{REVIEW OF RELATED LITERATURE}

\subsection{Teacher Union Support towards Teacher Welfare}

In a study conducted by KNUT (2002) on the role of the Kenya National Union of Teachers (KNUT) in promoting programmes aimed at improving teachers' welfare and socioeconomic for some primary school teachers in Mwingi District, Kenya, the findings indicated that the union had taken an initiative which works around improving teacher welfare by introducing incentives for their members. The study further revealed that low status, poor remuneration, constant ridicule in public and the mass media, the lack of fringe benefits, heavy workload, and deplorable working conditions have created a lot of despair amongst teachers. Against this background KNUT developed strategies that are aimed at addressing some of the gaps which could help improve the status of teachers.

Similarly, Rosco (2006) conducted a study on the role of the Namibia teachers' union in the development of the staffing norms policy in Namibia whose focus was on the role of stakeholders in the policy process played by the Namibia National Teachers' Union (NANTU) in the formulation of the staffing norms policy in Namibia. The findings indicated that NANTU was in policy making, an area that was traditionally perceived a management jurisdiction and performed its function professionalism. Findings also stressed the significance of stakeholder involvement in policy processes and provided a better understanding of the complex nature of policy. The study further indicated that NANTU helped teachers through its policy influence, the construction of staff rooms in schools.

In a study carried out by Karen (2015) on the perception of teachers on teacher union's representation at the school level in selected primary and secondary schools in Lusaka District $63(84 \%)$ of respondents perceived social welfare and workloads/enrolment as not being adequately represented by the union; 56(75\%) respondents felt supportive teaching environment has not been adequately addressed as well and 49 (65.3\%) of respondents indicated early confirmation has not well been represented. This literature shows that not much is being done by teacher unions in addressing teacher welfare and sustained livelihood.

Maravi (2002), observed that many teacher trade unions in Zambia have had challenges providing social welfare support to its members due to limited finances and resources to meet the demand of their members. However, despite teacher unions having limited financial capacity, they have the 
responsibility of sharing back the membership subscriptions to members so that they see benefits. The researcher further argues that teacher trade unions must work in a transparent manner so that the limited resources the union have could be shared with members. In contrast with the Zambian situation, teacher unions in South Africa, Uganda, Ghana and Kenya have significantly performed in the provision of social welfare to their members such as medical schemes, children's education schemes, burial and benevolent funds, credit facilities and mortgages (Adanisa, 2006).

In a study conducted by Julius (2015) on the contribution of teacher trade unions (TU) towards improving standards of teaching in Mkuranga district in Tanzania and various factors identified that were considered hindering TTU towards contributing to quality teaching included lack of political power to the union, absence of political support and poor recognition from the government.

On the effectiveness of teacher trade unions' strategies for enhancing teacher professional performance in public secondary schools in Kieni west District of Kenya, Wairagu (2013) observed that that the teachers' trade unions were instrumental in fighting for teachers' benefits and advocacy in education reform. However, motivation programmes for members were non-existent and the unions preferred pressuring the teachers' employer to provide motivation through better allowances and promotion opportunities. The study concluded that the increment of teachers' salaries and allowances motivated the teachers to some extent, an action which was supported by Simuyaba and Chibwe (2016).

According to Marius (2011) on a study conducted on the participation and influence of teacher trade unions in education reforms in Namibia, teacher unions play different roles in different political contexts, and that these roles are shaped by contextual factors.

Further studies in have revealed that Africa, unionized teachers earn about 20 percent more than their counterparts without unions (Blunch and Verner, 2004). The Global Wage Report 2010/11 (ILO, 2010) found that in South Africa workers without unions are at higher risk of low pay. The union-wage premium in Ghana is estimated at between 6 and 16 percent. Unionized workers in Cameroon receive a wage premium of 14 percent (Verner, 2006).

In Ghana, Otoo et al (2009) had estimated a strong positive correlation between unionization and workers' access to benefits and training. Within the framework of the collective bargaining process, trade unions have secured for workers a number of important social benefits that are employer-funded. These include but are not limited to educational scholarship, commonly called study with pay for workers (Ghana and Zambia), housing and accommodation loans or subsidies, funeral grants, interest-free loans and provident funds among others.
The literature reviewed indicates that studies conducted by various scholars indicate that trade unions in most countries were active in initiating programmes of for its members. However, from the same literatures fewer evidences showed how the initiated programmes improved welfare and livelihood of the members and how sustainable the programmes were. This is a gap in literature that requires an investigation.

\subsection{Contribution of Teacher Trade Unions to Members in African Perspective}

Studies on trade unionism in Africa (Perry, 1999; Randall, 2000; Meador, 2010) have shown that they played very important roles in the political, social and economic development of the continent. In the 1960s, trade unions in Africa were very instrumental in the struggle for independence across the continent. The findings revealed that, during independence struggle, trade unions across the continent offered the most important platform for ordinary people to voice their frustrations and to demand for selfdetermination. Also, post-political independence, trade unions in the continent have been at the forefront of the struggle for good governance, democracy, equality, fairness, respect for humans and workers' rights and social and economic justice.

Gad (1997) argues that trade unions have been weakened by incorporation of union officials within government corporate structures, making it difficult for them to challenge reform measures adopted by the government which are detrimental to the welfare and sustained livelihood of workers. Others (Donado, 2010; Kakuba, 2001) also argued that the strength of union representatives are usually weak compared to those of governments, thus diminishing their influence on decisionmaking. While this may be true in some countries, some studies have argued that the trade unions in countries like South Africa have remained strong and focused in representing workers, and have played a huge role in improving the welfare of workers.

According to Freeman and Madoff (1984) in a study conducted in the United States trade unions prefers single rate wage setting because it increases worker solidarity, equalizes pay between members, and decreases the uncertainty associated with having supervisors determine pay.

From a number of literatures on trade union work, about 91 percent of African countries have ratified the ILO Convention 89 on the right to organize and bargain collectively for improved workers' welfare by addressing the gaps which are identified as challenges among workers. Gabon, Niger, Tanzania, Uganda and Zambia have ratified Convention 154 on free Collective Bargaining. The Industrial and Labour Relations Act CAP 269 of the Laws of Zambia recognizes the free collective bargaining between trade unions and the employer for improved salaries and conditions of service for their members (Khabo, 2008). 


\subsection{Teacher Unions Achievements}

Wilson (2003) established that teacher trade unions who did not have reasonable membership, found it difficult to carry out the activities of the unions. This is a reason why the strength of teacher unions lies in high membership. Another study by Aluchio (2002:70) shows that, the Nigerian Union of Teachers had massively invested in its union due to high membership besides its own resources. Therefore, the financial capacity of any teacher union assists in good representation of teachers, and also in carrying out daily activities effectively.

Laine (2011) states that, Eastern and Western European countries such the United Kingdom, Finland, Norway and Italy show significant decline in membership. The decline in membership in some of these countries is due to some reasons as cited by Anyango (2001), who reveals that de-recognition and political manipulation. Georgelles (2010) observes that negotiations are not limited to wages, but also include staffing, medical, housing, transport, leave days allowance, safe and healthy work place, pension, equitable system of promotion and transfers, workable grievances systems, provision for continuing education and vacations.

Studies by Kelly (1998) and that of Simuyaba and Banda et.al (2015) further reveals that, there is low teacher morale among teachers in Sub-Sahara Africa and attributed this to low salaries and poor conditions of employment which in the long run reduced their status in the community. The study also revealed that, the inadequate representation of teachers' conditions of service by teacher unions poses a threat to the quality provision of education. This too was noted by Simuyaba and Chibwe (2015) in their study on teacher professionalism in Zambia. Teacher unions therefore must adequately fight for better conditions of service for their members so that teachers are motivated and are able to perform according to expectation in the provision of quality education.

\section{RESEARCH METHODOLOGY}

The study followed a descriptive research design. The population for research comprised all national teacher trade union officials; union teachers' members; and union leaders at school level. The respondents were selected through purposive, snowball and simple random sampling methods. Total sample size was consisted of 36 participants. That is, 4 national teacher trade union officials targeting one (1) official from each of the four national teacher trade union secretariats, 16 teachers, and 16 trade union leaders at school level of selected schools. The research collected data through in-depth interviews; focus group discussion and document review. Data collected through interviews; focus group discussion; and documentary review was thematically analysed, interpreted and presented descriptively.

\section{FINDINGS OF THE STUDY}

The study investigated the role of teacher trade unions in promoting teacher welfare and sustained livelihood for their members in Lusaka District of Zambia. The research objectives that guided the study were; to explore how the teacher unions have helped in promoting teacher welfare and sustained livelihood in Lusaka District, and to determine the measures that teacher unions may take to support the teacher welfare and sustained livelihood.

\subsection{Ways Teacher Unions Help in Promoting Teacher Welfare and Sustained Livelihood}

\subsubsection{Salary Increments}

The study found that teacher trade unions played a role of representing the teachers in collective bargaining which resulted in salary increments and improvement in other conditions of service for teachers. One teacher from teacher union ' $\mathrm{C}$ ' stated that:

Salary increments through collect bargaining process is the only role played by teacher trade union that everyone knows and seem to be beneficial to us although the bargaining process outcomes do not meet teachers' expectation. This is because they come out with very low increment.

According to the study salary increments were very critical in promoting teachers improved welfare and sustained livelihood despite the teacher unions not being very effective in bargaining for salary increments which are relative to economic situation at the time. One teacher from Union ' $D$ ' lamented that:

\section{I don't see any help from the roles that the unions play apart from signing for what government has decided already. They are toothless. Moreover, they enjoy better conditions of service and incentives from government and it does not bother them on what conditions government awards to teachers. They are interested in serving political interest and not the interests of the members. To me our union leadership is just greedy.}

The expectation from the teachers is that the collective bargaining should yield salary increment that should promote teacher welfare and sustained livelihood if the teachers were to appreciate the effectiveness of teacher unions' role in collective bargaining. The arguments by a number of teachers were that mostly the outcome of the bargaining process does not meet the minimum bread basket for the country.

\subsubsection{Conditions of Service for Teachers}

The conditions of service for teachers played a critical role in promoting improved teacher welfare and sustained livelihood. The findings of the study established that some teachers felt that collective bargaining did not help the general membership because teachers were delinked from national teacher unions' 
officials ruling on the increments on teachers' salaries and conditions of service. They felt that the $20 \%$ and $25 \%$ of basic salary as a commutation percentage on rural and remote hardship allowances was a mockery to teachers. Teachers stated that there were no consultative meetings with the teachers on matters of salary increments and conditions of service whenever there was collective bargaining. Teachers felt that they were to be consulted by their national leaders through union structures such as provincial, district and school-based four-member union leaders before signing for any offer by government. This finding is in line with Bendix (1991) that the lack of union influences on the decisionmaking processes could be ascribed to the absence of structures through which the unions could participate in order to influence educational policies and programs. This is also in consistency with Vaillant (2005) observation that teacher unions tend to adopt corporatist practices and cronyism. Under these practices, the unions operate like corporations, where the leadership takes decisions without the participation or involvement of the members. Teachers felt that the national union leadership were greedy; served political and their own interests; used unions funds collected from members to enrich themselves; and did not give teachers' needs the attention they required. Bendix (1998) notes, teacher unions can establish a position of equality with the employer and engage in collective bargaining, while teacher associations merely talk and rely on the goodwill of the employer.

The collective bargaining process did not help teachers because many teachers were highly indented and they blamed it to poor conditions of service. When teachers have a sustained livelihood and improved economic status, it also means that the conditions of service provided are favorable. If the level of borrowing is high among teachers, it was asserted that, it was due to the fact that the salary they are getting can't sustain their life demands.

\subsubsection{Advocacy}

Teachers indicated that teacher trade unions were very inactive in playing the role of advocates in presiding over disputes and matters that concerns teachers because some disputes teachers were left to resolve by themselves. One teacher commented that:

Teacher union as organizations are not bad, what is bad about them is that union leaders don't play their roles as expected and yet they know their roles very well. They are supposed to advocate and preside over matters that affect teachers' welfare and livelihood but they are just in their offices and driving expensive cars. We just represent ourselves when we have problems with our bosses at workplaces.

In instances where the teachers' trade unions advocacy was needed, teacher unions official were inaccessible and completely delinked from their members. Teachers felt left alone in matters such as; non receipt of housing and extra duty allowances, upgrade and reassessment of salary scale, non- receipt of rural and remote allowances, anarchy in staff transfers and promotions. This is in line with Adelberg (2008) who found that teacher union leaders viewed themselves as advocates for the best interests of their members. Majority of teachers also confirmed that their respective unions were not involved in advocacy activities that were aimed at improving their welfare and sustained livelihood. Teacher unions did not play their role and yet they knew their role of advocacy. The implication of the study is that teacher welfare and sustained livelihood can improve if there is advocacy to ensure that teachers are not exploited in the matters and disputes that concerns them. This is one very important responsibility of the teacher trade unions in Zambia as provided by the 2006 Industrial and Labour Relations Act of the Laws of Zambia.

\subsubsection{Support to Member in Times of Bereavement}

Bereavements are a natural calamity that affects teacher welfare because it affects the emotion, physical and psychological wellbeing of the bereaved person. Teacher trade unions did not play their role of support to bereaved members. The study found that teacher expected teacher unions to come to their aid in times of difficulties such as funerals. The study further reviewed that union leaders show full commitment to some funerals especially those for members close to the unions' leaders, union leadership members or relation to union leaders; and to some mare members. Sometimes teacher unions show less commitment, concern and support and yet the member contributes monthly to the union through subscriptions. One teacher from Teacher Union ' $\mathrm{C}$ ' narrated thus:

Sometimes what the union does is not fair.

We are all equal and we make equal monthly contributions. However, we see teacher unions show strong commitment and provide full support at some funerals of members and to others, nothing was done. [Me] when I lost my son, the teacher union where I pay my monthly subscription never provided any support towards my plight and did not even attend despite informing them. And it's not me alone we see this happen to other members when they have bereavement.

Teachers observed that teacher trade unions only send messages of condolences and no material or financial support. The study revealed that sometimes teacher trade unions supported bereaved families although no clear standard could be traced which guides them regarding such support. This finding is consistency to the finding of Meena (1997) who argues, "Teachers union members usually work alone in this struggle for a better life." They did not get support from other workers who were going through more or less similar crises. If all union members with the same crises joined together they could defeat the government and make their lives better. The study established that there was biasness in the provision of support to teachers who pay equal monthly subscription to a 
particular teacher union when it comes to some form of support.

\subsubsection{Financial Assistance to Members}

One of the roles teacher trade unions are supposed to play in the educational reforms was to support the professional development of their members in a number of ways. However, the study revealed that very few members from all the teachers had benefited from any form of financial assistance and most documents in unions didn't show any clear financial support system.

This prompted the teachers to wonder whether the teacher trade unions had financial support scheme towards education because they indicated not to have received any formal communication from teacher trade union on how to access financial assistance; and teachers expressed ignorance about education assistance funds which was mentioned by national union leaders.

Some teachers never received any education assistance from my union despite them writing letters in request for financial assistance. One national teacher trade union official from Teacher Union ' $\mathrm{C}$ ' indicated that:

We do not sponsor members to further their education. All we provide is education assistance funds to help them with other educational requisites such as books, pens and even pay for small costs. Our education assistance ranges between five hundred kwacha (K500) to one thousand kwacha (K1000) as a when a member applies for it. But generally the demand is quiet high now. We spend about thirty thousand kwacha (K30, 000) per month as head office. Government seems not to have human resource development program for its serving teachers.

One teacher from teacher union ' $\mathrm{C}$ ' observed that:

I am not sure if my teacher union provides education assistance fund because I spent 4 years studying for my bachelor degree program and I had never received any education assistance from my union. However, I have never missed not even a single month to remit the monthly subscription to the teacher union. If there is education assistance, then it is done on anarchy grounds.

This shows that teacher trade unions did not provide a role of supporting professional development seriously through different strategies. The finding is contrary to a study by Bascia (2000) who found that teacher trade unions improve professional development and teacher training. On his writing he portrayed that local teacher trade unions had professional development committees which were engaged in professional development activities, preparation, providing learning materials, and hosting conferences for teachers, and providing some form of financial support. This finding was not in consistency with Vaillant (2005) who observed that in some countries, the unions have included the professional development of teachers' in-service training as one of their basic functions through financial support to members. The policy emphasizes the need for increased teacher training at all levels and the creation of the necessary conditions for the professional development of teachers.

\subsubsection{Worker Education}

The study found that leaders of the four member unions in both primary and secondary schools were not providing any worker education programmes to members at local levels. It found a gap in worker education by teacher unions in that there was minimal established link between the four-member union leaders and teachers to create a platform for conducting worker education at local level. The worker education using the television and radio was not effective as the topics aired were mostly to inform the nation and not to educate the workers directly on areas of need.

\subsubsection{Loan Facility Empowerment}

The study revealed that some teacher trade unions provided loan facility empowerment to their members. The loan scheme was a good programme to improve their welfare and livelihood. The loan facilities included land empowerment loan and building materials loan. One teacher explained that:

Provision of land loan to members by the unions is a good move but if they want us teachers to get land loans they should first improve the conditions of service first. If am getting K3000, and they say that am supposed to be paying K1, 500 every month for 5years, then I will be remaining with $K 1,500$ and I am supposed to pay for house rentals, pay school fees for the children, buy food, pay utility bills. If I get land it means that my welfare and livelihood would be affected for the next 5years or so. It's also not clear if the union is subsidizing on the same land. It looks like the cost of land is the same with other land business institutions. Land from the union should be cheaper.

Study also revealed that the schemes were expensive as most of the teachers were failing to access the loan as their salaries were below the threshold for qualifying for the loan. The loan facilities ended up not benefiting all the members because they were not affordable to majority of them who already owed other lending institutions.

\subsection{Measures to support improved teacher welfare and sustained livelihood}

The study also sought to ascertain the measures that teacher trade unions can take to support improved teacher welfare and sustained livelihood. A number of responses were given and these were grouped into the themes that emerged as follows:

\subsubsection{Soft Loan Empowerment Scheme for Members}

The study established that teacher trade unions have no soft loan scheme facility that allows teacher members access soft 
financial loans. Most participants in the study wondered as to where the union membership subscriptions go when almost every teacher in the Ministry of General Education contributes monthly to a particular teacher union. Teachers indicated that the amount that is deducted monthly on the pay slip (if was not deducted) could be used by a teacher to supplement the funds for family welfare and sustained livelihood. However, the findings of the study revealed that the contributions that members made to union organizations were not kept as a revolving fund to benefit teacher members in times of financial needs. Teachers interviewed said that there was no financial report for the expenditure of union organizations funds year in year out to report on how the funds collected in a particular year were used and how it helped the ordinary members. But the study further revealed that all the interviewed teacher unions had audited financial statements which were unqualified and those statements were approved by the Delegates during the Annual Conferences. Teachers proposed that initiation of financial soft loan scheme for members and provision of salary advance to teachers on a minimal interest could contribute to improvement of teachers' welfare and thereby creating sustained livelihood.

\subsubsection{Enhanced Teacher Unions Contact with General Membership}

The study findings indicate that the teacher trade unions at school, district, province, and national secretariat level had delinked themselves from the general membership. Teachers did not know their teacher trade union leadership as they did not visit to check on the welfare and working conditions of their general membership. The study further revealed that provincial and national teacher union leadership was very greedy and selfish in that they spend a lot at that level. This is contrary to Laine (2010) who describes the roles of local union representatives as to regularly communicate with members, advice members, assist teachers resolve issues, promote needs and interests of teachers in schools, ensure all members are in benefit, and ensure that members are aware of rights and responsibilities.

The study revealed that meetings between teacher members and union representatives at the school level were not held regularly. This is contrary to the studies by Bennell (2003) who indicated that meetings between teachers and unions were important as they focused on updates and finding out teacher's grievances. The finding is contrary to Terry (2006) who also observed those meetings between teachers and trade union representatives, channels teachers' different views and grievances and places them before management, as it is impossible for management to view their grievances.

Local union representatives are crucial in the attainment of adequate representation, because they have direct contact with teachers and are aware of the needs of the teachers. Therefore, Teacher trade union representation should not only center on improving teachers' pay alone, but also addressing all issues affecting teachers at the school level. The non-contact between teacher union leadership and the general membership would lead to membership leaving the particular union organization and joining elsewhere where leadership is accessible.

\subsubsection{Mortgage Scheme}

The study revealed that teacher accommodation was a problem in both primary and secondary schools in Lusaka; one of the roles of teacher trade union was to fight for decent housing for teachers or reasonable housing allowance to allow teachers rent decent and standard accommodation; teachers in primary and secondary schools were renting houses in low cost areas because rentals in Lusaka district were very high and teachers could not afford to rent a decent house. Living in low cost house affected the livelihood of teachers. Teacher trade unions with their monthly income from members' contributions can build housing units and rent them out to those wanting decent accommodation to rent at a subsidized rate and those who would want to buy at a relatively lower price. This is in consistency with Laine (2011) who observed that research done in Western Europe and United States of America also revealed that, teacher unions use the subscriptions to assist members with various issues such as finances, mortgages, medical insurances, children's allowances for members and educational allowance for members. Therefore, from the findings it is clear that, teachers don't have a direct benefit from their subscriptions.

The implication of these findings is that if the problem of teacher accommodation is not addressed, the scourge would continue to affect the welfare and sustained livelihood of teachers and in turn affect their job performance. Hence decent housing can give teachers a settled mind and enhance concentration on their work performance in schools

\subsubsection{Decentralization of Teacher Unions Functions}

The study noted that teacher trade unions were ignorant of the key role played by teachers unions apart from the role of bargaining and speaking for teachers right sand better conditions of service for teachers. The following is the excerpt from one teacher:
It is a very awkward situation that many teachers belong to teacher trade unions and know nothing about how they operate, functions and the departments it has and what the workers in the directorates do towards improving members' welfare and sustain their livelihood. Its only individuals who work at national union secretariats who know what is involved in the operation of teacher unionism and the rest know very little if not nothing.

It was further revealed that the general membership of teacher trade unions were ignorant of the roles played by teacher trade unions apart from the role of bargaining; national and provincial teacher union leaders performed functions that were only known to themselves and delinked from their 
general membership. The implication of these findings is that non accessible leadership and direct impact of the operations to teachers unions can lead to teachers union losing its credibility and membership. This also had a negative impact on the welfare of teachers because of a huge information gap that existed with the structures of the teacher trade unions.

\subsubsection{Housing Units for Teacher}

The study found that some Primary and Secondary schools had enough land within the school boundaries where teacher's houses could be built by teacher unions in partnership with government. National teacher trade unions' officials acknowledged lack of innovations TO consider this idea which in the long run help teachers rent their own teacher trade unions' housing units. On average teachers were paying $\mathrm{K} 100$ to the unions every month and Teacher Unions; A'; 'C'; and ' $\mathrm{B}$ ' had over 20000 memberships across the country which shows that every month these teachers unions received over K2, 000,000 from their members. The implication of this findings are that if teachers occupies that teacher trade unions house, the teacher trade unions would bargain for reasonable housing allowance for them to realize good money from the housing initiatives and in turn contribute positively to improving of teacher welfare and sustained livelihood. Seeking (2004) argues that self-interest has led teachers and their unions in post-apartheid South Africa to oppose, block or impede some reforms which would improve the quality of schooling for poor children because teachers felt not properly housed to poor communities.

\subsubsection{Health Insurance Scheme}

The study established that the welfare and sustained livelihood of teachers also was about their physical health well-being. The study found that none of the teacher trade unions had a facility for health scheme and even government did not have a health scheme for teachers in public schools. The teachers indicated that unions were more concerned about their funeral than their health because there was a funeral scheme for teachers. The participants viewed that teacher trade unions could improve the welfare of members by opening health scheme for members and a negotiated rate with medical service providers and trades unions to pay for such services from members' subscriptions. One teacher echoed that:

We do not have a health scheme for teachers from both government and teacher unions and the cost for good health services in Zambia are quiet high. A health scheme would be a good union initiative because it would have a direct impact on the wellbeing of a member, and we will feel that our subscriptions are working on us not the way things are now. Currently things are bad because teachers can't afford high cost medical service, and how can a union claim to be improving our welfare if our health is not covered. We would appreciate a medical scheme than receiving a shirt costing K20.We have heard people say a health nation is a prosperous nation and I think a health teacher is a prosperous teacher.

The teachers observed that from the monthly subscriptions the members contribute to the trade unions $10 \%$ of the contribution can go towards health insurance so that when one member fell sick they would be able to get medical attention through the scheme. The study revealed that welfare and sustained livelihood of teachers also concerns their health well-being; none of the teacher trade unions had a facility for health scheme; teacher trade unions could improve the welfare of members by opening health scheme of members because this facility will affect directly the welfare and livelihood of their members.

\section{CONCLUSIONS AND RECOMMENDATIONS}

Based on the findings on research revealed that teacher trade unions were very inactive and had no documented strategies that were aimed at promoting teacher welfare and sustained livelihood which were outside the collective bargaining processes. The study further revealed that some teachers were left alone to pursue and follow-up cases which needed the help of the teacher unions and some of the cases had directly affecting teacher welfare and sustained livelihood. In some cases, it was clear that teacher trade unions were more reactive to challenges affecting their members than being proactive. Cases cited included; non receipt of housing and extra duty allowances, upgrade and reassessment of salary scale, no receipt of rural and remote hardship allowances which have a direct impact on the income for teachers. According to the study teacher trade unions are only more proactive when it comes to collective bargaining on improved salaries and conditions of service but that the said process has never met the members' expectations. The study concludes that teacher trade unions were not active in playing the role of presiding effectively over matters that concerned the teachers because in most disputes teachers felt that teacher trade unions sided with the administrators. Collective bargaining results were not meeting the expectations of teachers and the loan scheme facility a good programme to improve their welfare and livelihood however, it was expensive to access as their salaries were below the thresh hold for qualifying for them.

On measures that teacher trade unions take to support improved teacher welfare and sustained livelihood, proposed possible measures as; coming up with resource mobilization strategies that would help in increasing the financial base of teacher trade unions. Other key activities recommended bordered around providing soft loan scheme to members on a minimal interest rate; provision of salary advance; enhance and improve frequent contact with the general membership at all levels of leadership; establish clear channels of support towards all members with similar challenges such a funeral events. The study concluded that teacher trade unions could come up with initiatives such as; building houses and giving them to teachers as mortgage loans at subsidized rates, or even 
give them to teachers on rent at reduced rates since they are built using teachers' money; devolution of functions through decentralization of some function to structures at the lower levels; and opening of health schemes for members in order for the general membership to have access to good medical facilities.

These recommendations are made on the basis that teacher trade unions should consider addressing the issues regarding the plight of teachers' welfare and sustained livelihood as priority. In this regard, teacher trade unions should come up with programs that will have a direct benefit on the livelihood of teachers. Secondly, the teacher trade unions should hold mutual consultative meetings with their members in order for them to represent them effectively. In order for teacher trade unions to share with education management teams on the aspirations of teachers if education, such consultations should also be extended to the Ministry of General Education.

\section{REFERENCES}

[1] Adesina, A.M. (2011). Trade Union Leadership Structure and the Challenges of Politics; Ilorin, Nigeria.

[2] Anderson, J.E. (2003). Public policymaking. An introduction. Boston: Houghton Mifflin.

[3] Bascia, N. (2005). Triage or tapestry? Teacher union's ' work in an era of systemic reform. In

[4] Bendix, S. (1991). Industrial relations in South Africa. Cape Town: Juta.

[5] Gad, L. (1997). The Impact of Structural Adjustment on Trade Unions in Egypt. PhD Thesis,University of Warwick.

[6] Garret, R.M (1999). Teacher job satisfaction in Developing countries. London: DFID.

[7] Georgelles, A. (2010), Teacher union and Educational Reforms. California: Sage Publishing.

[8] Harris, J (2010). 'Globalizations(s) and Labour in China and India: Introductory Reflection', Global Labour Journal 1(1): 3-11.

[9] Herman, Jerry, J (1998). "With Collaborative Bargaining, You Work with the Union NotAgainst It." The American School Board Journal 172, 41-42, 47.

[10] Hugget, R. (1996). Business Studies for GCSE. Second Edition. London: Harper Collins.

[11] ILO (2004). Trade Unions and Poverty Reduction Strategies. Geneva: ILO

[12] Kakuba, C.C. (2001). Trade Unions and Labour Policies. Lusaka: Zambia PublishingCompany.
[13] Kelly, J. (1998). Rethinking Industrial Relations: Mobilization, collectivism and Long Waves,London, Routledge.

[14] Kuhn, G. (1998). Collective Bargaining and Labour Relations: Prentice Hall, Indiana.

[15] Laine, D. (2011). Are Unions Members Happy? Evidence from Eastern and Western Europe.

[16] Maravi, E. (2002). The Rebirth of Unionism in Zambia. Lusaka: Multimedia Publications.

[17] MoGE (2016). Annual Report for 2015, Ministry of General Education: Lusaka.

[18] Mwilima, N. (2008). The Role of Trade Unions in Job Creation: A case study of the JobCreation

[19] Trust; A research report submitted to the Faculty of Humanities,University of the Witwatersrand, Johannesburg, South Africa.

[20] Patillo, K.M. (2012). Quiet Corruption: Teacher Unions and Leadership in South African Schools. Honours thesis. Middletown, Connecticut: Wesleyan University.

[21] Ratteree, B. (2004). Teachers, their Unions and the Education for All campaign, Background paper prepared for the Education for All Global Monitoring Report 2005, The Quality Imperative. USA

[22] Seekings, J. (2004).Trade unions, social policy and class compromise in post-apartheid South Africa. Review of African Political Economy, 100:299-312.

[23] Veerle, D. and Enslin, P. (2002). Democracy in education or education for democracy: The limits of participation in South African School governance. Journal of Education, 28, School of Education, University of Natal: 5-25

[24] Von Holdt, K (1994). The rise of strategic unionism. Retrieved on 9/24/2010 from: http://www.africafiles.org/article.asp?ID =4702.

[25] SIDA (2000). Teacher education, Teachers' conditions and motivation. Stockholm: Author.

[26] SimuyabaL E and Chibwe, P. Teacher Professionalism in Zambia: Practices, Challenges and Prospects in the Post 2015 Era. Proceedings of the $67^{\text {th }}$ International Conference on Education, art and Social Sciences, Stockholm, Sweden, April 2016, Available on http://worldresearchlibrary.org.proceedings.php. Pp 17-21. (ISNB 978-93-8597389-5)

[27] Simuyaba, E. Banda D, Mweemba L and Muleya G, Theory againist Practice, Training of Teachers in a Vacuum, Journal of Education and Social Policy, Vol.2, No 4); December, 2015.

[28] Wood, G (1998). Trade Union recognition: cornerstone of the new South AfricanEmployment Relations. Johannesburg: Thomson International Publishing.

[29] Wood, D (1996). The Politicization of Teachers' associations in the Cote d' Ivoire. African Studies Association, Vol.39, No.3:113129.

[30] Zengele, T. (2010), Teacher Unions, Redeployment, Employment of Educators Act No. 76 of 199 Collective Agreements. Page 17, 32.

[31] ZNUT. (2012). the Teachers' Voice. Volume 19 December 2012. 